\title{
Development of PR genes panel for screening aphid-tolerant cultivars in Brassica juncea
}

\author{
R. Sandeep Raj ${ }^{1} \cdot$ Sonal V. Thakur ${ }^{1} \cdot$ Vora Shebhan Hussen $^{1} \cdot$ Madhvi N. Joshi $^{1}$ • \\ Shradha Nand Tyagi $^{1} \cdot$ Snehal B. Bagatharia ${ }^{1}$
}

Received: 16 November 2016/ Accepted: 21 March 2017/Published online: 1 June 2017

(C) Springer-Verlag Berlin Heidelberg 2017

\begin{abstract}
The exorbitant yield loss incurred by Indian farmers every year (10-90\%) in rapeseed-mustard (Brassica juncea) is chiefly attributed to the progressive infestation of mustard fields by Lipaphis erysimi (Kalt.), a major insect pest belonging to the family of Homoptera. Currently there are no successful tolerant cultivars developed by conventional means in Brassica juncea with systemic plant responses in the form of direct or indirect defenses against aphid attack. Lack of specific methods for screening large numbers of genotypes required in breeding for selection of tolerant cultivars in mustard is one of the main causes of slow progress in developing resistant varieties of Brassica juncea. Traditional phenotype-based breeding has to be augmented with recent molecular approaches for potential genotype selection and cultivar development in Brassica juncea. In current study a pathogen-responsive gene panel was developed which could be used for expression-assisted breeding program in mustard for selection of tolerant types against aphid infestation, minimizing the huge crop losses suffered by farmers every year.
\end{abstract}

Keywords Brassica juncea - Lipaphis erysimi . Pathogen-responsive genes $\cdot$ Gene expression

Electronic supplementary material The online version of this article (doi:10.1007/s13205-017-0785-7) contains supplementary material, which is available to authorized users.

R. Sandeep Raj

rsandeepraj@gmail.com; sandeep@gujaratgenomics.in

1 Department of Science and Technology, Government of Gujarat, Gujarat State Biotechnology Mission, 11th Block, 9th Floor, Udyog Bhavan, Gandhinagar 382 011, Gujarat, India

\section{Introduction}

Indian mustard (B. juncea) is the major oilseed crop of the Indian sub-continent belonging to the rapeseed-mustard group. It accounts for nearly $27 \%$ of total edible oil production of the country. India ranks third in the world and first in Asia, both in terms of acreage and production of mustard; however, India's average yield of mustard is low in comparison to other mustard-growing countries chiefly due to aphid pest causing excessive losses in the yield of the crop (Pandey et al. 2013; Rao et al. 2014).

The mustard aphid, Lipaphis erysimi (Kalt.), causes damage to the crop in the range of 9-96\% across different agro-climatic conditions of India (Hasan and Singh 2011). Patel et al. (2004) reported Lipaphis erysimi as the most serious pest affecting mustard crop and causing yield loss in the range of 35.4-91.3\% under different thermal environments in eastern central India. Kular and Kumar (2011) conducted field studies to assess the losses in seed yield of different Brassica species (B. juncea, B. napus, B. carinata, B. rapa and Eruca sativa) due to infestation of insect pests. The loss in seed yield, due to mustard aphid and cabbage caterpillar, varied from 6.5 to $26.4 \%$. Bakhetia (1984) observed a $57.8-80.6 \%$ yield loss due to mustard aphid. In Haryana, Singh et al. (1993) reported $38.20-46.56 \%$ yield losses in susceptible cultivars under unprotected conditions.

The nymph as well as the adult form of $L$. erysimi covers the entire surface of flower buds, shoots and pods in large numbers and feeds on different parts of the plants by sucking the cell sap (Hasan and Singh 2011). Malik and Deen (1998) observed that infestation of $L$. erysimi on $B$. juncea causes reduction in plant height, number of branches per plant, siliqua per plant, grains per siliqua, seed yield, oil content and oil yield. The aphid damages the crop 
from the seedling stage to the maturity stage. L. erysimi was also found infesting the roots at depths of $2-15 \mathrm{~cm}$. Infestation of 38-63 aphids on the roots of individual plants caused $42 \%$ plant mortality in the first week of January (Singh and Singh 1988). Singh et al. (1983) also reported reduction in yield of Indian mustard by $1.5 \mathrm{~kg} / \mathrm{ha}$ for each increase of 1 aphid beyond 25 aphids/plant in Punjab. Weather plays an important role in the appearance, multiplication and disappearance of mustard aphid (Kumar et al. 1999; Vekaria and Patel 2000). A large number of field and laboratory studies indicate that insect abundance increases with rising temperature (Cannon 1998; Bale et al. 2002). In warm humid climate, the time to attain peak population was relatively shorter than in cool climate (Rao et al. 2014).

Plant traits which help in basal defenses against aphid infestation are cell wall modifications, proteins or secondary metabolites that have antixenotic antibiotic properties and plant volatiles that repel aphids or attract their natural enemies. Aphids also induce transcripts associated with plant hormones known to modulate disease resistance, including jasmonic acid (JA), salicylic acid (SA), ethylene, abscisic acid (ABA) and gibberellic acid (Goggin 2007; Wang et al. 2009).

Taj et al. (2011) elucidated co-expression and in silico interaction studies for interlinking the activation of $M A P K 3$ and $L O X$ genes during the pathogenesis of Alternaria brassicae in Brassica juncea. The study suggested that the induction of $J A$ biosynthesis required $M A P K 3$ activation and pointed out that interactions of $M A P K 3$ genes with $L O X$ and its proposed role in biosynthesis of JA/JA induced the expression of defense genes in mustard. Bhardwaj et al. (2015) carried out a transcriptomic study in Brassica juncea cultivar Varuna to detect genome-wide changes in its transcriptome against high temperature or drought stress. The study revealed that the maximum number of upregulated transcription factors in high temperature and drought stress belonged to heat shock factors (HSFs) and dehydration-responsive element-binding (DREB) families, respectively. Bandopadhyay et al. (2013) performed a transcriptomic study to identify the genes involved in resistant response in wild crucifer Rorippa indica during $L$. erysimi infestation. Plant disease resistance involves the SA-dependent signaling which is effective against biotrophs and JA/ET-dependent signaling against necrotrophs. Aphids use decoy defense strategy by induction of less effective SA-dependent defense response and suppression of JA-dependent pathways, but incompatible interaction studies revealed JA dominance in later phase in R.indica leading to canceling of decoy trap and effective resistance.

In the present study, 14 candidate genes were selected for the development of PR genes panel to estimate the intensity of aphid infestation in B.juncea. The expression level of 14 candidate genes in different samples of B.juncea having varying levels of aphid infestation were analyzed by real-time PCR.

\section{Materials and methods}

\section{Sample collection}

Aphid-infested plant parts of GM 3 variety of Brassica juncea were collected from a field in Pethapur $\left(23^{\circ} 16.676 \mathrm{~N}\right.$ and $\left.72^{\circ} 39.664 \mathrm{E}\right)$, Gandhinagar, Gujarat. Pod, stem and leaf samples having varying level of aphid infestation and control samples were collected and the number of aphids per centimeter of plant part was counted for pod, stem and leaf samples (Prasad et al. 1983).

\section{Aphid identification through sequencing}

DNA was extracted from aphid using DNeasy Blood and Tissue Kit (Qiagen) and quantitated on QIAxpert (Qiagen). PCR amplification was carried out in $20 \mu \mathrm{l}$ volume using ReadyMix $^{\mathrm{TM}}$ Taq PCR Reaction Mix (Sigma), $10 \mu \mathrm{M}$ of LCO_1490 (GGTCAACAAATCATAAAGATATTGG) and HCO_2198 (TAAACTTCAGGGTGACCAAAAAAT CA) primers and $50 \mathrm{ng}$ of extracted DNA. PCR was performed under the following conditions: $2 \mathrm{~min}$ at $94{ }^{\circ} \mathrm{C}$; five cycles of $1 \mathrm{~min}$ at $94^{\circ} \mathrm{C}, 1.5 \mathrm{~min}$ at $45^{\circ} \mathrm{C}$ and $1.5 \mathrm{~min}$ at $72{ }^{\circ} \mathrm{C} ; 35$ cycles of $1 \mathrm{~min}$ at $94{ }^{\circ} \mathrm{C}, 1.5 \mathrm{~min}$ at $50{ }^{\circ} \mathrm{C}$ and $1 \mathrm{~min}$ at $72{ }^{\circ} \mathrm{C}$ and a final cycle of $5 \mathrm{~min}$ at $72{ }^{\circ} \mathrm{C}$. End point analysis of PCR-amplified product was done on $2 \%$ agarose gel. The 658 bp product was purified using Exosap (Affymetrix) and sequenced using LCO_1490 and HCO_2198 primers using 3500XL Genetic Analyzer (Applied Biosystems), with BigDye ${ }^{\circledR}$ Terminator v3.1 Cycle Sequencing kit (Applied Biosystems).

\section{RNA extraction and cDNA preparation}

The samples were placed in RNAlater tubes to capture and preserve all the transcripts during aphid infestation in field. RNA was isolated from control and aphid-infested leaf, pod and stem samples using RNeasy Plant Mini Kit (Qiagen). The extracted RNA was quantified on QIAxpert (Qiagen) and $300 \mathrm{ng}$ was used as the final concentration for the preparation of cDNA using High Capacity cDNA Reverse Transcription kit (Applied Biosystems).

\section{Selection of genes for development of PR genes panel and qPCR}

All the primers used in the study for the development of PR genes panel were selected from the works of Taj et al. (2011), 
Table 1 List of genes selected for PR panel development

\begin{tabular}{|c|c|c|c|c|}
\hline $\begin{array}{l}\text { Sr. } \\
\text { No. }\end{array}$ & Gene & Gene name & Function & References \\
\hline 1 & $A P 2$ & Apetala2 & Nuclear transcription factor, and controls flower and seed development & Sun et al. (2012) \\
\hline 2 & TIR1 & Transport inhibitor response 1 & $\begin{array}{l}\text { Ubiquitination of transcription repressors AUX/IAA, promoting } \\
\text { expression of auxin repressor gene }\end{array}$ & Sun et al. (2012) \\
\hline 3 & SNAP & Senescence-associated protein & Induced during senescence and pathogen infections & $\begin{array}{l}\text { Sun et al. (2012), } \\
\text { Espinoza et al. } \\
(2007)\end{array}$ \\
\hline 4 & $M A P K$ & $\begin{array}{l}\text { Mitogen-activated protein } \\
\text { kinase }\end{array}$ & $\begin{array}{l}\text { Plant MAPK cascades regulate stress and hormonal responses, innate } \\
\text { immunity, and developmental programs }\end{array}$ & $\begin{array}{l}\text { Rodriguez et al. } \\
\text { (2010), Taj et al. } \\
\text { (2011) }\end{array}$ \\
\hline 5 & GP3 & Germin-like protein & $\begin{array}{l}\text { Zygotic and somatic embryogenesis, salt stress, pathogen elicitation, } \\
\text { heavy metal stress }\end{array}$ & Sun et al. (2012) \\
\hline 6 & PRH43 & $\begin{array}{l}3^{\prime} \text {-phosphoadenosine }-5^{\prime}- \\
\text { phosphosulfate reductase } \\
\text { homolog }\end{array}$ & Involved in sulfate assimilation & Sun et al. (2012) \\
\hline 7 & $D R E B 2 B$ & $\begin{array}{l}\text { Dehydration-responsive } \\
\text { element-binding proteins }\end{array}$ & $\begin{array}{l}\text { Induces the expression of cold-responsive gene, which leads to } \\
\text { enhanced cold/frost tolerance in plants; highly expressed during } \\
\text { drought stress }\end{array}$ & $\begin{array}{l}\text { Bhardwaj et al. } \\
\text { (2015) }\end{array}$ \\
\hline 8 & $60 S$ & $60 \mathrm{~S}$ ribosomal subunit & Protein synthesis & Sun et al. (2012) \\
\hline 9 & HSP101 & Heat shock protein 101 & $\begin{array}{l}\text { Involved in refolding of proteins which form aggregates under heat } \\
\text { stress }\end{array}$ & $\begin{array}{l}\text { Bhardwaj et al. } \\
\text { (2015) }\end{array}$ \\
\hline 10 & LEA1 & $\begin{array}{l}\text { Late embryogenesis abundant } \\
\text { proteins }\end{array}$ & $\begin{array}{l}\text { Regulation of plastid organization and biosynthesis, expressed during } \\
\text { high temperature and drought conditions }\end{array}$ & $\begin{array}{l}\text { Bhardwaj et al. } \\
\text { (2015) }\end{array}$ \\
\hline 11 & $S A C 9$ & $\begin{array}{l}\text { SAC-domain containing } \\
\text { protein }\end{array}$ & $\begin{array}{l}\text { SAC9 phosphatase is involved in modulating phosphoinositide signals } \\
\text { during stress response }\end{array}$ & Sun et al. (2012) \\
\hline 12 & $L O X$ & Lipoxygenase & $\begin{array}{l}\text { Enzyme of JA pathway associated with A number of developmental } \\
\text { stages, mobilization of lipids during germination, defense against } \\
\text { pest, antimicrobial activity }\end{array}$ & Taj et al. (2011) \\
\hline 13 & $R R T F$ & $\begin{array}{l}\text { Ethylene-responsive } \\
\text { transcription factor } 109\end{array}$ & $\begin{array}{l}\text { Mediates cross talk between JA signaling and auxin biosynthesis to } \\
\text { regulate lateral root formation }\end{array}$ & Sun et al. (2012) \\
\hline 14 & HSFA7A1 & Heat shock factor A7A1 & Highly expressed during high temperature stress conditions & $\begin{array}{l}\text { Bhardwaj et al. } \\
\text { (2015) }\end{array}$ \\
\hline 15 & ACT3 & Actin & $\begin{array}{l}\text { Ubiquitous component of plant cytoskeleton. Involved in cell division, } \\
\text { plane localization, cell elongation and cell shape determination }\end{array}$ & Sun et al. (2012) \\
\hline
\end{tabular}

Bhardwaj et al. (2015) and Sun et al. (2012) (Table 1). Primer sequences of all the genes used in the panel development study are furnished in Table 2. Real-time PCR was performed to quantify the fold-level change in all the genes during aphid infestation. The cycling condition was set as per the manufacturer's protocol mentioned in the Power SYBR Master Mix kit (Applied Biosystems).

\section{Relative quantification}

Analysis for the relative quantification data for all the targets was done using DataAssist bioinformatics tool. DataAssist $^{\mathrm{TM}}$ software utilizes the comparative CT ( $\Delta \Delta \mathrm{CT}$ ) method (Livak and Schmittgen 2008) to quantitate relative gene expression across a number of genes and samples. DataAssist platform was used to create the RQ plot of 14 candidate genes. RQ is the fold change in expression of a gene in a sample compared to the calibrator sample. The calibrator has an RQ value of 1 . For graphical representation, $\log 10$ value of fold change was plotted against the sample. Heat map genes were hierarchically clustered by Pearson correlation coefficient using complete linkage. Box plot displays the overall range of CT distribution for each sample from all genes in the experiment. Different samples give the average CT value, minimum CT value and maximum $\mathrm{CT}$ value of the sample corresponding to its respective gene.

\section{Analysis for PR genes panel elucidation}

Selection of genes for PR gene panel from 14 candidate genes was carried out based on genes registering maximum representation in various sample types. Heat map graphically displays the results by hierarchical clustering. Distances 
Table 2 Primer sequences of genes selected for PR gene panel development

\begin{tabular}{|c|c|c|c|}
\hline \multirow{2}{*}{$\begin{array}{l}\text { Sr. } \\
\text { No. } \\
1\end{array}$} & \multirow{2}{*}{$\begin{array}{c}\text { Gene } \\
A P 2\end{array}$} & \multicolumn{2}{|c|}{ Primer sequence } \\
\hline & & $\mathrm{F}$ & GATTCGCCGATTCTTGAT \\
\hline & & $\mathrm{R}$ & TCTGCTTCTTTCCTGGTCG \\
\hline \multirow[t]{2}{*}{2} & $D R E B 2 B$ & $\mathrm{~F}$ & GCTCCAGATCAAGAGGATG \\
\hline & & $\mathrm{R}$ & CGAGTCAGTCTGAGGTG \\
\hline \multirow[t]{2}{*}{3} & LEA 1 & $\mathrm{~F}$ & GCATGCTGAGGTCAGC \\
\hline & & $\mathrm{R}$ & CCAGCTTCATGCTGCG \\
\hline \multirow[t]{2}{*}{4} & $L O X$ & $\mathrm{~F}$ & AGAAATGCTTGCTGGGCTAA \\
\hline & & $\mathrm{R}$ & GCTCAGTGTCGTTCTGGACA \\
\hline \multirow[t]{2}{*}{5} & $M A P K 3$ & $\mathrm{~F}$ & CGTACACTTCGCGAGATCAA \\
\hline & & $\mathrm{R}$ & ATTCATTCGGTTGCTGCTCT \\
\hline \multirow[t]{2}{*}{6} & HSP101 & $\mathrm{F}$ & CAAGGATATCTACATACCTCGTAAC \\
\hline & & $\mathrm{R}$ & CATAGCCATCCAAATGATACTTTG \\
\hline \multirow[t]{2}{*}{7} & HSFA7A1 & $\mathrm{F}$ & CTGTCCCAAGAGAAACCCTTC \\
\hline & & $\mathrm{R}$ & GTCGTCTGGGATTTGCATTC \\
\hline \multirow[t]{2}{*}{8} & TIRl & $\mathrm{F}$ & AAGGCTCAGACGGAAACA \\
\hline & & $\mathrm{R}$ & TGCTGGTCTTGAGGTGCT \\
\hline \multirow[t]{2}{*}{9} & $G P 3$ & $\mathrm{~F}$ & CAGCGAGTTCTTGATTGTC \\
\hline & & $\mathrm{R}$ & CGATTTCCGTCTTGGTCT \\
\hline \multirow[t]{2}{*}{10} & PRH43 & $\mathrm{F}$ & GAAGTGGAACCCTTTGGC \\
\hline & & $\mathrm{R}$ & CATCCATCGTCCTCAAGAA \\
\hline \multirow[t]{2}{*}{11} & SAC9 & $\mathrm{F}$ & GCCAATCTGCCTCCAGTTC \\
\hline & & $\mathrm{R}$ & GATACGTCAAGTCTTTCACTGC \\
\hline \multirow[t]{2}{*}{12} & SNAP & $\mathrm{F}$ & GCGGTATACCTGTTAAACGATAACG \\
\hline & & $\mathrm{R}$ & CCACAAGCCAGTTATCCCTGTG \\
\hline \multirow[t]{2}{*}{13} & $R R T F$ & $\mathrm{~F}$ & TTACAGCCTAAACAACCATC \\
\hline & & $\mathrm{R}$ & TTCTCCAGCAATAGCACAG \\
\hline \multirow[t]{2}{*}{14} & $60 S$ & $\mathrm{~F}$ & CAGTGATCTTCACAGCCTTCT \\
\hline & & $\mathrm{R}$ & TTATGAATCTTCCCAGCAACT \\
\hline \multirow[t]{2}{*}{15} & ACT3 & $\mathrm{F}$ & GGCTACTCTTTCACCACGAC \\
\hline & & $\mathrm{R}$ & GGATACCAGCATTCTCCATAC \\
\hline
\end{tabular}

between samples and assays are calculated for hierarchical clustering based on the $\Delta \mathrm{CT}$ values using pearson's correlation distance. Heat map portrays the expression of the 14 pathogen-responsive genes; the color scale illustrates the relative expression level of pathogen-responsive genes, representing $\Delta \mathrm{CT}$. Green indicates genes with relatively decreased levels of expression, whereas red indicates genes with relatively increased levels of expression.

\section{Results}

\section{Aphid infestation load}

Aphid load was estimated by counting the number of aphids per centimeter of plant part (Prasad et al. 1983). Aphid infestation load is furnished in Table 3.

\section{Sequencing of mustard aphid}

The COI gene of mustard aphid was amplified and sequenced. The sequence analysis using nucleotide BLAST revealed the most identical homology match with two sequences (Table 4): Lipaphis pseudobrassicae with accession number EU701711.1 and Lipaphis erysimi with accession number KP189473.1.

\section{Gene expression of PR genes}

Compared to the control leaf (L1) sample in L2 sample, 60S, AP2, DREB2B, MAPK, GP3 and TIRl genes were upregulated in the fold range between 2.46 and 36.01 , and HSFA7A1, LEA1, LOX, PRH43, RRTF, SAC9, SNAP and HSP101 genes were downregulated in the fold range between 0.00 and 0.57 . In the L3 sample compared to the 
Table 3 Aphid load in different plant parts

\begin{tabular}{|c|c|c|c|c|}
\hline Sr. No. & Sample type & Sample code & Aphid/cm & Average \\
\hline \multirow[t]{4}{*}{1} & \multirow[t]{4}{*}{ Stem } & $\mathrm{S} 1$ & 0 & \multirow[t]{4}{*}{41} \\
\hline & & $\mathrm{S} 2$ & 14 & \\
\hline & & S3 & 30 & \\
\hline & & $1 \mathrm{~S} 4$ & 80 & \\
\hline \multirow[t]{4}{*}{2} & \multirow[t]{4}{*}{ Pod } & $\mathrm{P} 1$ & 0 & \multirow[t]{4}{*}{25} \\
\hline & & $\mathrm{P} 2$ & 15 & \\
\hline & & P3 & 20 & \\
\hline & & $\mathrm{P} 4$ & 40 & \\
\hline \multirow[t]{4}{*}{3} & \multirow[t]{4}{*}{ Leaf } & L1 & 0 & \multirow[t]{4}{*}{40} \\
\hline & & L2 & 10 & \\
\hline & & L3 & 40 & \\
\hline & & L4 & 70 & \\
\hline
\end{tabular}

Table 4 BlastN results which hold homology with the sequenced amplicon

\begin{tabular}{|c|c|c|c|c|c|c|}
\hline Sr. No. & Accession & Description & Total score & Query coverage $(\%)$ & $E$ value & Max ident (\%) \\
\hline 1 & EU701711.1 & Lipaphis pseudobrassicae & 1109 & 93 & 0 & 97 \\
\hline 2 & KP189473.1 & Lipaphis erysimi & 1098 & 93 & 0 & 96 \\
\hline
\end{tabular}

control L1, AP2, GP3, LOX, MAPK, SNAP and TIR1 genes were upregulated in the fold range between 1.2 and 363.06, while HSFA7A1, 60S, DREB2B, LEA1, PRH43, RRTF, $S A C 9$ and HSP101 genes were downregulated in the fold range between 0.00 and 0.4 . In the $L 4$ sample compared to the control, L1, AP2, GP3, LOX, MAPK, PRH43 and TIR1 genes were upregulated in the fold range between 3.73 and 91.23, while HSFA7A1, 60S, DREB2B, LEA1, SNAP, $R R T F, S A C 9$ and HSP101 genes were dowregulated in the fold range between 0.01 and 0.39 .

Compared to the control stem (S1) in the S2 sample, AP2, DREB2B, HSFA7A1, HSP101, LEA1, MAPK, PRH43, RRTF, SAC9, SNAP and TIR1 genes were upregulated in the fold range between 1.23 and 655.94, while $60 S, G P 3$ and $L O X$ genes were downregulated in the fold range between 0.15 and 0.84 . In the $\mathrm{S} 3$ sample compared to the control S1 sample, $A P 2, M A P K$ and $S N A P$ genes were upregulated in the range of 1.09-82.61, while $D R E B 2 B$, HSFA7A1, HSP101, LEA1, PRH43, RRTF, SAC9 and TIR1 genes were downregulated in the fold range between 0.00 and 0.94. In the S4 sample compared to the S1 sample, $A P 2, M A P K, S N A P$ and TIR1 genes were upregulated in the fold range between 1.47 and 13.57, while $D R E B 2 B$, HSFA7A1, HSP101, LEA1, PRH43, RRTF and SAC9 genes were downregulated in the fold range between 0.00 and 0.97 .

Compared to the control pod (P1) sample in the P2 sample, 60S, AP2, DREB2B, GP3, MAPK, PRH43, RRTF, SAC9, SNAP, TIR1, HSP101 and LEAl genes were upregulated in the fold range between 1.15 and 41.23, while $H S F A 7 A 1$ and $L O X$ genes were downregulated in the fold range between 0.07 and 0.21 . In the P3 sample compared to the P1 sample, 60S, AP2, DREB2B, GP3, PRH43, SAC9, SNAP, TIR1, HSP101 and LEAl genes were upregulated in the fold range between 1.3 and 43.11, while HSFA7A1, LOX, MAPK and RRTF genes were downregulated in the fold range between 0.06 and 0.65 . In the P4 sample compared to the control P1 sample, AP2, GP3, PRH43, SNAP and TIR1 genes were upregulated in the fold range between 1.25 and 70.82 , while $60 S, D R E B 2 B$, HSFA7A1, HSP101, LEA1, LOX, MAPK, RRTF and SAC9 genes were downregulated in the fold range between 0.15 and 0.97 (Table 5; Figs. 1, 2, 3).

\section{PR gene panel elucidation}

\section{Cluster analysis using heat map}

Based on $\Delta \mathrm{CT}$ value assessed in an assay-centric fashion, 14 genes were divided into two major nodes. In the first major node, there were six sub-nodes which include genes PRH43, RRTF, LEA1, SAC9, HSFA7A1 and HSP101. The second major node encompassed nine sub-nodes including genes LOX, MAPK, SNAP, 60S, DREB2B, TIR1, ACT3, $A P 2$ and GP3. Genes GP3, AP2 and TIR1, PRH43 capture the differential expression pattern ranging from higher fold levels (red coloration) to lower fold levels (green coloration), making them best suited for PR gene panel development. MAPK, DREB2B (green gradient) and SNAP (red gradient) show gradient pattern in coloration, allowing them to capture the differential response of plant tissues during aphid infestation (Fig. 4). 
Table 5 Fold change expression levels of pathogen-responsive genes

\begin{tabular}{|c|c|c|c|c|c|c|c|c|c|}
\hline Assay & L2 & L3 & $\mathrm{L} 4$ & S2 & $\mathrm{S} 3$ & $\mathrm{~S} 4$ & $\mathrm{P} 2$ & P3 & $\mathrm{P} 4$ \\
\hline $60 S$ & 2.73 & 0.09 & 0.39 & 0.15 & 0.02 & 0.67 & 10.89 & 7.54 & 0.97 \\
\hline$A P 2$ & 2.62 & 1.20 & 15.52 & 1.99 & 1.09 & 1.47 & 13.42 & 1.62 & 2.98 \\
\hline$D R E B 2 B$ & 2.73 & 0.17 & 0.22 & 1.23 & 0.56 & 0.53 & 41.23 & 28.61 & 0.37 \\
\hline$G P 3$ & 22.93 & 1.34 & 41.49 & 0.30 & 0.94 & 0.97 & 4.54 & 3.53 & 5.17 \\
\hline$H S F A 7 A 1$ & 0.03 & 0.40 & 0.07 & 151.61 & 0.10 & 0.03 & 0.21 & 0.20 & 0.25 \\
\hline HSP101 & 0.00 & 0.03 & 0.37 & 74.75 & 0.84 & 0.03 & 1.15 & 1.76 & 0.50 \\
\hline$L E A 1$ & 0.02 & 0.04 & 0.05 & 655.94 & 0.63 & 0.21 & 6.96 & 2.18 & 0.37 \\
\hline$L O X$ & 0.57 & 4.10 & 9.30 & 0.84 & 0.05 & 0.02 & 0.07 & 0.17 & 0.37 \\
\hline$M A P K$ & 2.46 & 3.06 & 6.30 & 469.35 & 9.55 & 2.09 & 4.47 & 0.65 & 0.15 \\
\hline PRH43 & 0.00 & 0.00 & 3.73 & 90.05 & 0.00 & 0.72 & 27.23 & 43.11 & 70.82 \\
\hline$R R T F$ & 0.00 & 0.06 & 0.01 & 28.03 & 0.02 & 0.10 & 1.59 & 0.06 & 0.18 \\
\hline SAC9 & 0.07 & 0.05 & 0.01 & 28.56 & 0.04 & 0.00 & 2.31 & 1.30 & 0.21 \\
\hline$S N A P$ & 0.30 & 3.27 & 0.34 & 170.98 & 82.61 & 13.57 & 3.96 & 1.52 & 1.25 \\
\hline$T 1 R 1$ & 36.01 & 363.06 & 91.23 & 14.50 & 0.22 & 6.71 & 3.85 & 3.76 & 3.00 \\
\hline
\end{tabular}

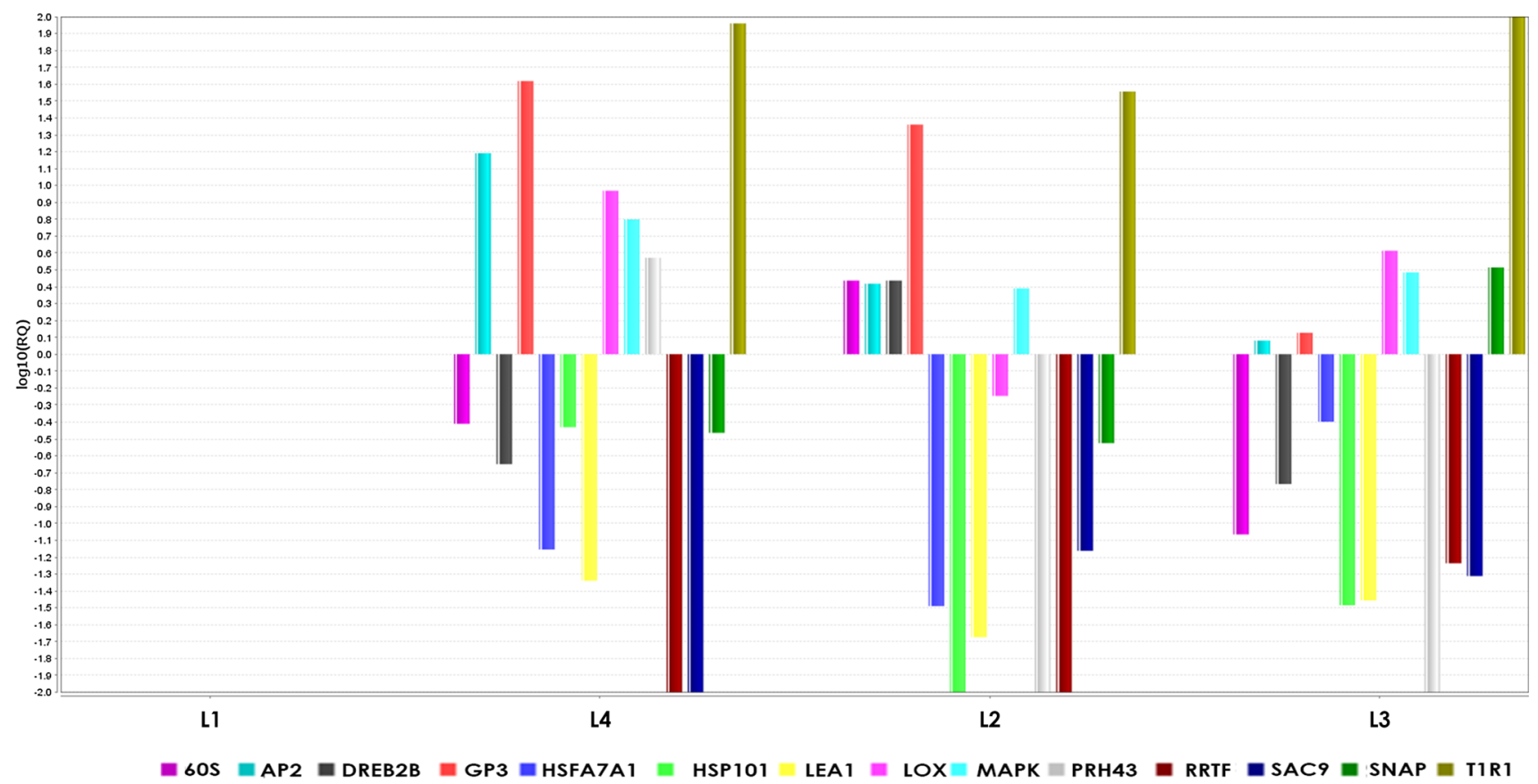

Fig. 1 RQ plot of 14 PR genes for leaf samples having varying levels of aphid infestation

\section{Selection of genes for the development of PR gene panel}

Selection of genes for the development of PR gene panel was done based on their expression in aphid-infested and control samples. Among the upregulated genes, AP2, TIR1, SNAP, MAPK, GP3, PRH43 and DREB2B are the best candidate genes for the development of the PR gene panel, as these genes are expressed in most of the sample tissues (Table 6).

\section{Discussion}

Aphids reproduce at a higher rate during the early vegetative stage of mustard plants when the developmental period is shortest and the production of winged morphs is lowest. The nymphs and adults cause damage by sucking away the plant sap, often covering the entire surface of the shoots, floral buds and pods. The insect pests cause enormous yield and economic losses in Brassica crop 


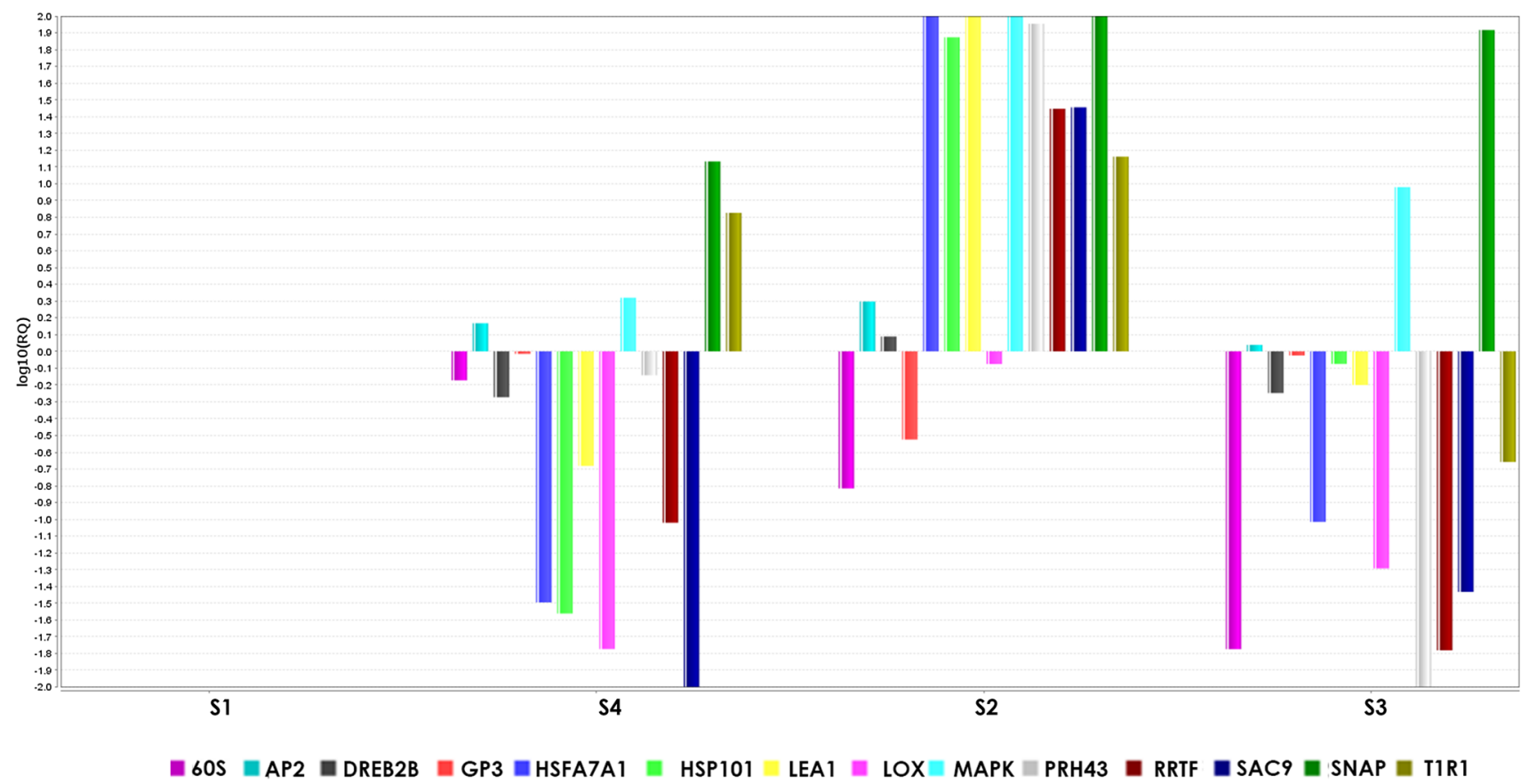

Fig. 2 RQ plot of 14 PR genes for stem samples having varying levels of aphid infestation

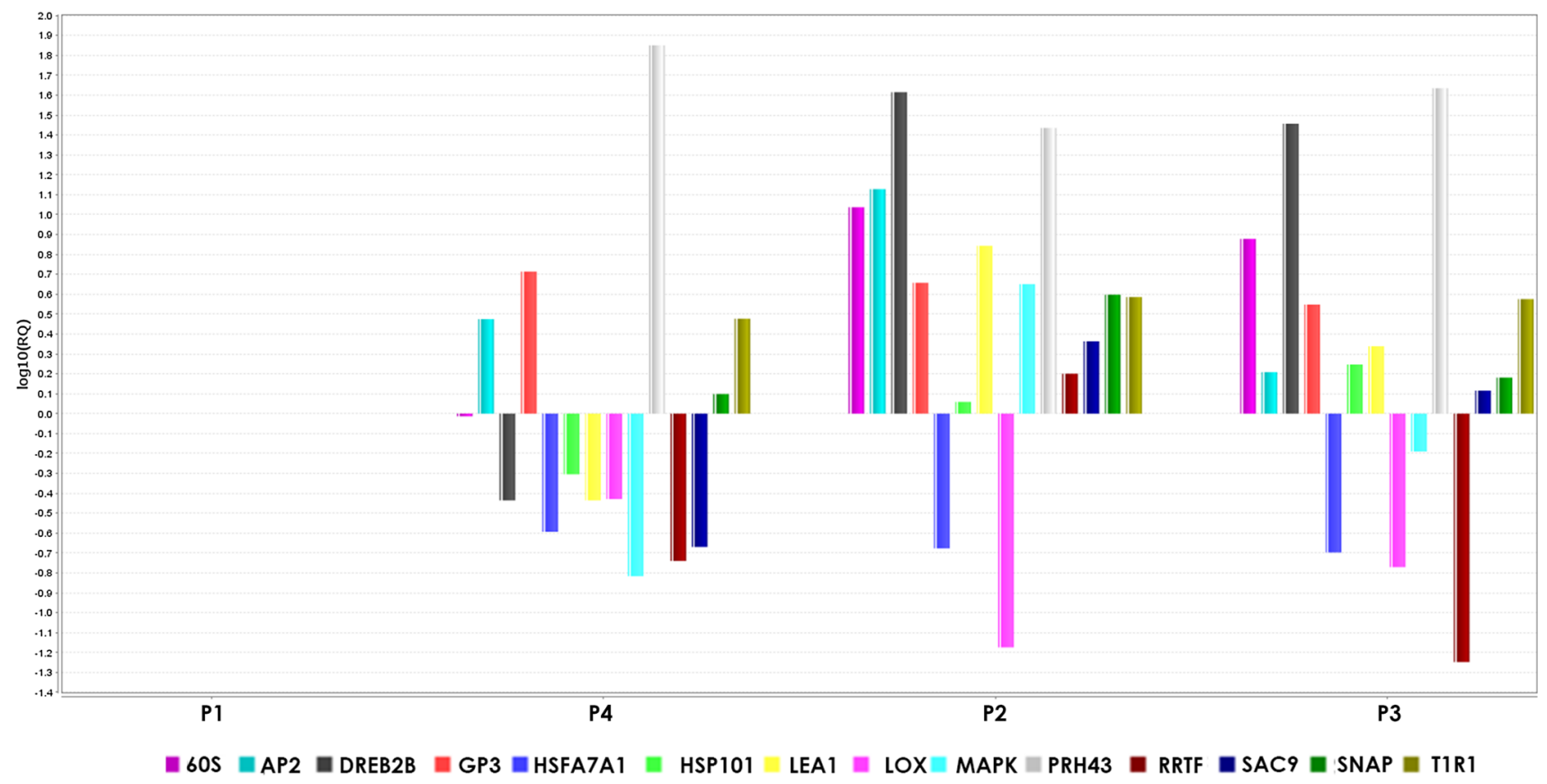

Fig. 3 RQ plot of 14 PR genes for pod samples having varying levels of aphid infestation

production every year, and are a threat to global agriculture. Several studies have shown that weather plays an important role in the appearance; multiplication and disappearance of mustard aphid (Kumar et al. 1999; Vekaria and Patel 2000; Hossain et al. 2006) and a large number of field and laboratory studies indicate that insect abundance increases with rising temperature (Cannon 1998; Bale et al.
2002). The effect of global warming on plant insect interaction is projected as the reason for increase in herbivore pressure on plant (Coley 1998). In the present investigation, the aphid infestation load in leaf, stem and pod was enumerated to be greater than 25 numbers $/ \mathrm{cm}$ of plant body, signifying high infestation of pest on mustard plants (Singh et al. 1983). 


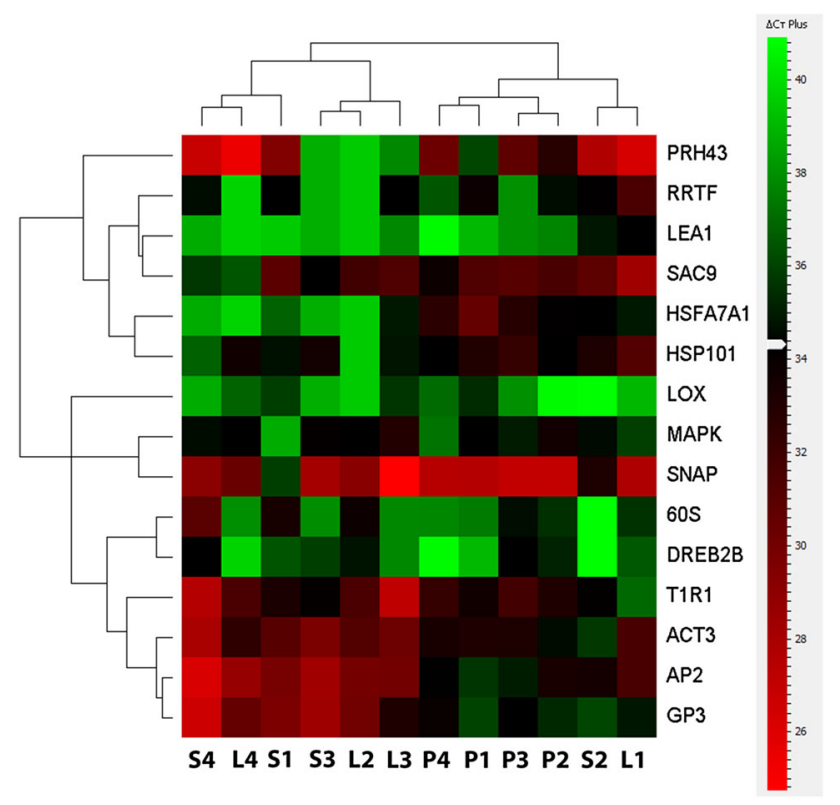

Fig. 4 Heat map analysis of 14 PR genes in assay-centric fashion

Table 6 Pathogen-reponsive gene panel ranking

\begin{tabular}{llll}
\hline Sr. No. & Assay & $\begin{array}{l}\text { Upregulated sample } \\
\text { number }\end{array}$ & Ranking \\
\hline 1 & AP2 & 9.0 & 1 \\
2 & T1R1 & 8.0 & 2 \\
3 & MAPK & 7.0 & 3 \\
4 & SNAP & 7.0 & 3 \\
5 & GP3 & 6.0 & 4 \\
6 & PRH43 & 5.0 & 5 \\
7 & DREB2B & 4.0 & 6 \\
8 & 6OS & 3.0 & 7 \\
9 & HSP101 & 3.0 & 7 \\
10 & LEA1 & 3.0 & 7 \\
11 & SAC9 & 3.0 & 7 \\
12 & LOX & 2.0 & 8 \\
13 & RRTF & 2.0 & 8 \\
14 & HSFA7A1 & 1.0 & 9 \\
\hline
\end{tabular}

The present methods of aphid control in mustard are primarily based on synthetic chemical insecticides. These chemicals, besides aggravating environmental pollution, can also be toxic to friendly insects. A resistant cultivar is always a more sustainable and environment-friendly option for managing insect pests. Hence, development of an insect-resistant cultivar having a heritable and transferable resistance is the most sustainable option (Stoner and Shelton 1988; Ahuja et al. 2010). The development of resistant cultivar through breeding programs for insect resistance is conducted mainly by first surveying for possible sources of insect resistance (antixenosis, antibiosis, tolerance) in varieties and strains locally available and hybridization to combine genes for resistance with desirable agronomic characters followed by screening for resistance characters in hybrid progenies (Warwick 2011; Smith and Chuang 2014). The evaluation of resistance is mainly carried out using parameters such as seedling survival, aphid injury to plants, aphid infestation, aphid fecundity and yield evaluation (Kavitha and Reddy 2012). These screening parameters are carried out in field and are not economical in time and effort. Hence, fast and more accurate detection methods for measuring the basal defense responses in breeding progenies has to be used in combination with visual parameters of screening for resistance in hybrid breeding programs. In the present study, expression of 14 defense-responsive genes assimilated from studies of Taj et al. (2011), Bhardwaj et al. (2015) and Sun et al. (2012) was quantified in stem, leaf and pod sections of GM 3 variety of mustard (Brassica juncea) sampled from an aphid-infested field located at Pethapur, Gandhinagar, Gujarat. Non-infested stem, leaf and pod sections were taken as calibrator control samples during relative quantitation study with $A C T 3$ gene as the endogenous control.

Goggin (2007) implicated plant traits involved in basal defenses such as cell wall modifications, proteins or secondary metabolites that have antixenotic or antibiotic properties and plant volatiles that repel aphids or attract their natural enemies. Aphids also induce transcripts associated with plant hormones known to modulate disease resistance, including jasmonic acid (JA), salicylic acid (SA), ethylene, abscisic acid (ABA), auxins (AUX) and gibberellic acid. Bandopadhyay et al. (2013) elucidated some pathogen-responsive genes involved during wild crucifer Rorippa indica resistance response on infestation of mustard with aphid Lipaphis erysimi. The time course relative expression level profiles of 24 genes induced in $R$. indica on forced infestation with $L$. erysimi at different time points, viz. $6,12,24,48 \mathrm{~h}$ post-infestation were analyzed by quantitative real-time analysis. Candidates comprising the largest group of genes during aphid-induced defense signaling were that of SAdependent signaling, which is effective against biotrophs and JA/ET-dependent signaling against necrotrophs. In the present study, genes involved in the above-mentioned pathways were included for the development of the PR gene panel for capturing the role of phytohormonal cross talk in plant defense signaling during aphid attack.

The main aim of the study was to elucidate a fast and accurate PR gene panel which could be used for molecular screening of commercial, wild relatives and mutant lines of mustard plant in breeding programs. The development of aphid-tolerant mustard plants is better option than developing plants with high levels of antibiosis resistance, as the latter will promote the development of aphid virulence. Hence in the present investigation, major focus was given to genes involved in basal defense mechanisms. Based on the results of the 


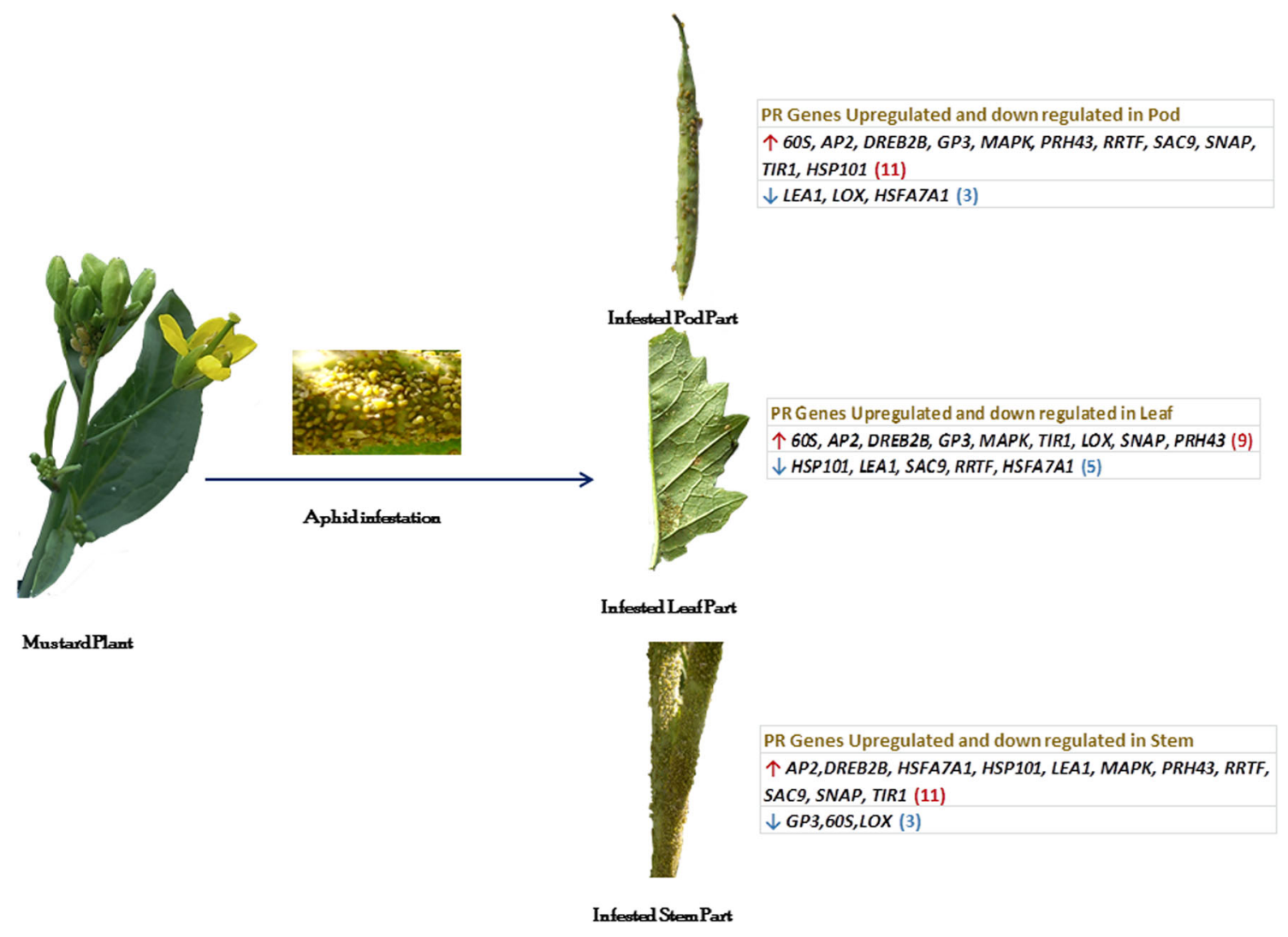

Fig. 5 Candidate PR genes showing up/downregulation and downregulation in Brassica juncea

relative expression stipulated in the RQ plot, heat map and ranking of genes in different sample tissues $A P 2, T I R 1, S N A P$, $M A P K, P R H 43$ and $D R E B 2 B$ were constantly found upregulated. The final panel of six PR genes also signifies a combinatorial effect of biotic stress and abiotic stress prevalent in the field. The aphid count analysis also showed the highest infestation levels in the stem and leaf followed by pod. An interesting observation made during the study was even when the aphid load was less in the pod section of the mustard plant, the number of upregulated genes in the pod was highest compared to the stem section which had the highest infestation of aphid. This reveals that defense mechanisms are in their prime functionality in pod samples, as they constitute the most important parts of mustard plants (Fig. 5). Aphid virulence in newly developed mustard hybrids can also be derived by correlating the upregulation of genes to the intensity of aphid attack which can be quantified in a seasonal study.

\section{Conclusion}

The present study is the first attempt in Gujarat to quantify selected genes of biotic and abiotic stress defense pathways in mustard plant during aphid infestation. The study also further establishes the reason for huge loss incurred by the farmers while growing GM 3 variety of mustard in the field, as it shows low resistance to aphid attack in Gujarat. The study also points to the urgent need for development of tolerant varieties of mustard to combat aphid attack and seasonal screening of developed varieties using PR gene panel to check the development of aphid virulence. The PR gene panel explicated in the present study could be used to screen commercially available accessions of mustard along with land races via sick plot studies to select tolerant types, leading to the expression-assisted breeding of mustard, tolerant to aphid infestation, thus minimizing the huge crop losses incurred by farmers every year.

Acknowledgements This work was supported by the Department of Science and Technology, Government of Gujarat, under The Gujarat Biodiversity Gene Bank (BioGene) Scheme, GSBTM.

\section{Compliance with ethical standards}

Conflict of interest The author(s) declare no competing financial interests and there is no conflict of interest.

\section{References}

Ahuja I, Rohloff J, Bones AM (2010) Defence mechanisms of Brassicaceae: implications for plant-insect interactions and

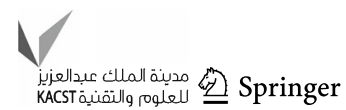


potential for integrated pest management. A review. Agron Sustain Dev 30(2):311-348

Bakhetia D (1984) Chemical control of Lipaphis erysimi (Kaltenbach) on rape seed and mustard crop in Punjab. J Res Punjab Agric 21:7-63

Bale JS, Masters GJ, Hodkinson ID, Awmack C, Bezemer TM, Brown VK, Butterfield J, Buse A, Coulson JC, Farrar J, Good JEG, Harrington R, Hartley S, Jones TH, Lindroth RL, Press MC, Symrnioudis I, Watt AD, Whittaker JB (2002) Herbivory in global climate change research: direct effect of rising temperature on insect herbivores. Glob Change Biol 8:1-16

Bandopadhyay L, Basu D, Sikdar S (2013) Identification of genes involved in wild crucifer Rorippa indica resistance response on mustard aphid Lipaphis erysimi challenge. PLoS ONE. doi:10. 1371/journal.pone.0073632

Bhardwaj A, Joshi G, Kukreja B, Malik V, Arora P, Pandey R, Shukla R, Bankar K, Agarwal S, Goel S, Jagannath A, Kumar A, Agarwal M (2015) Global insights into high temperature and drought stress regulated genes by RNA-Seq in economically important oilseed crop Brassica juncea. BMC Plant Biol. doi:10. 1186/s1287001404051

Cannon RJC (1998) The implications of predicted climate change for insect pests in the UK, with emphasis on non-indigenous species. Glob Change Biol 4:785-786

Coley PD (1998) Possible effects of climate change on plant/ herbivore interactions in moist tropical forests. Clim Change 39:455-472

Espinoza C, Medina C, Somerville S, Arce-Johnson P (2007) Senescence-associated genes induced during compatible viral interactions with grapevine and Arabidopsis. J Exp Bot 58(12):3197-3212

Goggin F (2007) Plant-Aphid Interactions: molecular and ecological perspectives. Curr Opin Plant Biol 10(4):399-408

Hasan W, Singh C (2011) Field assessment of Mustard aphid, Lipaphis erysimi (Kalt.) On cultivars of Indian mustard (Brassica juncea L.). Ann Plant Protect Sci 19:51-54

Hossain MA, Maiti MK, Basu A, Sen S, Ghosh AK, Sen SK (2006) Transgenic expression of onion leaf lectin gene in Indian mustard offers protection against aphid colonization. Crop Sci 46(5):2022-2032

Kavitha K, Reddy KD (2012) Screening Techniques for different insect pests in crop plants. Int $\mathrm{J}$ Bioresour Stress Manag 3(2):188-195

Kular J, Kumar S (2011) Quantification of avoidable yield losses in oilseed Brassica caused by insect pests. J Plant Prot Res 51(1):38-43

Kumar J, Malik Y, Singh S (1999) Forecasting model for outbreak of Lipaphis erysimi on some cultivars of mustard (Brassica juncea). Indian J Entomol 61:59-64

Livak KJ, Schmittgen TD (2008) Analyzing real-time PCR data by the comparative CT method. Nat Protoc 3:1101-1108
Malik YP, Deen B (1998) Impact of aphid, Lipaphis erysimi (Kalt.) intensity on plant growth and seed characters of Indian mustard. Indian. J Entomol 60(1):36-42

Pandey R, Kumar B, Kumar M (2013) Genetic divergence for quantitative traits in Indian Mustard (Brassica juncea L. Czern \& Coss). Am Eurasian J Agric Environ Sci 13(3):348-351

Patel S, Awasthi A, Tomar R (2004) Assessment of yield losses in mustard (Brassica juncea L.) due to mustard aphid (Lipaphis erysimi Kalt.) under different thermal environments in Eastern Central India. Appl Ecol Environ Res 2(1):1-15

Prasad SK, Phadke KG, Mehrotra KN (1983) Forecasting of Mustard Aphid, Lipaphis erysimi Kaltenbach on Rapeseed crop. Proc Indian Nat Sci Acad B 50:146-153

Rao B, Rao V, Nair L, Prasad Y, Ramaragan A, Chattopadhyay C (2014) Mustard aphid infestation in India Development of forewarning models. J Environ Biol 35:683-688

Rodriguez MC, Petersen M, Mundy J (2010) Mitogen-activated protein kinase signaling in plants. Annu Rev Plant Biol 61:621-649

Singh D, Singh H (1988) Inheritance of white rust resistance in interspecific crosses of Brassica juncea Lx B. carinata L. Crop Res 1:189-193

Singh B, Singh R, Mahal MS, Brar HS (1983) Assessment of loss in yield of Brassica juncea by Lipaphis erysimi (Kalt) I. influence of varying aphid population. Indian. J Ecol 10(1):97-105

Singh H, Singh B, Gupta S (1993) Response of mustard aphid, Lipaphis erysimi (Kalt.) to different cultivars of Brassica under protected and unprotected conditions. J Insect Sci 6:117-118

Smith CM, Chuang WP (2014) Plant resistance to aphid feeding: behavioral, physiological, genetic and molecular cues regulate aphid host selection and feeding. Pest Manag Sci 70(4):528-540

Stoner KA, Shelton AM (1988) Influence of variety on abundance and within-plant distribution of onion thrips (Thysanoptera: Thripidae) on cabbage. J Econ Entomol 81(4):1190-1195

Sun Q, Zhou G, Cai Y, Fan Y, Zhu X, Liu Y, He X, Shen J, Jiang H, Hu D, Pan Z, Xiang L, He G, Dong D, Yang J (2012) Transcriptome analysis of stem development in the tumourous stem mustard Brassica juncea var. tumida Tsen et Lee by RNA sequencing. BMC Plant Biol. doi:10.1186/1471-2229-12-53

Taj G, Agarwal P, Grant M, Kumar A (2011) Co-expression and in silico interaction studies for inter-linking the activation of MAPK3 and LOX genes during pathogenesis of Alternaria brassicae in Brassica juncea. J Oilseed Brassica 2:13-20

Vekaria M, Patel G (2000) Screening of promising Brassica and allied genotypes for resistance against mustard aphid, Lipaphis erysimi Kalt (Homoptera:Aphididae). Appl Biol Res 4:75-77

Wang X, Kong H, Ma H (2009) F-box proteins regulate ethylene signaling and more. Genes Dev 23(4):391-396

Warwick SI (2011) Brassicaceae in Agriculture. In: Schmidt R, Bancroft I (eds) Genetics and Genomics of the Brassicaceae. Springer, New York, pp 33-65 